\title{
POWERS OF THE LOCAL AUTHORITY IN REGULATING LAND PLANNING AND DEVELOPMENT CONTROL: WHITHER CONTROL
}

\author{
Ainul Jaria Maidin ${ }^{1} \&$ Bashiran Begum Mobarak Ali ${ }^{2}$ \\ Ahmad Ibrahim Kulliyyah of Laws \\ INTERNATIONAL ISLAMIC UNIVERSITY MALAYSIA
}

\begin{abstract}
Land use planning in Malaysia as regulated by the Town and Country Planning Act 1976 ("Act 172") vests in the local authorities' wide powers and responsibility for managing and carrying on the daily administration of land use planning decision making and development control regime. This article examines the powers of the local authority in regulating land planning and development control and the power of the courts in exercising control over the exercise of the discretionary powers of the local authority.
\end{abstract}

Keywords: Local authority, Land planning and development control, indemnity, judicial supervision

\section{INTRODUCTION}

Local authorities assume an extremely important role in the administration of local authority areas. A local authority is a unit within the system of local government and is established to manage its affairs ${ }^{3}$. The local authority administration is a politico-administrative system, constituted by law, and having devolved powers. The United Nations has defined it as a political subdivision of a nation or (in a federal system) state which is constituted by law

\footnotetext{
1 Assistant Professor, Public Law Department, Ahmad Ibrahim Kulliyyah of Laws, International Islamic University, Malaysia LL.B(Hons.) (IIUM); Master in Comparative Laws (IIUM); Ph.D. (UWA, UK); Non-Practising Advocate and Solicitor, High Court of Malaya. (Email: ainulj@iiu.edu.my).

${ }^{2}$ Assistant Professor, Private Law Department, Ahmad Ibrahim Kulliyyah of Laws, International Islamic University, Malaysia LL.B(Hons.) (IIUM); Master in Comparative Laws (IIUM); Ph.D. in Business Law (UPM). (Email: bashera@iiu.edu.my).

${ }^{3}$ The United Nations considers both the terms local government and local authorities as synonymous and as such can be used interchangeably.
} 
and has substantial control over local affairs, including the power to impose taxes ${ }^{4}$.

The local authority construct, operate, and maintain economic, social and environmental infrastructure, oversee land planning and development control processes, establish local environmental policies and regulations, and assist in implementing national and sub-national environmental policies. As the level of government closest to the people, they play a vital role in educating, mobilizing and responding to the public to promote sustainable development. ${ }^{5}$ Towards realizing this, the local authorities are vested with wide discretionary powers by the empowering legislation o as to enable it to manage the local authority area's planning and development control matters for the principal purpose of ensuring comfort for the residents. It is thus useful to examine the powers of the local authority in administering the land planning and development control regime and the extent of its discretionary powers as well as the role of the courts in supervising the exercise of the discretionary powers.

\section{INSTITUTIONAL AND ADMINISTRATIVE FRAMEWORK}

The hierarchy of administration of the local authority is the creation of the Federal Constitution Malaysia 1957 ("Federal Constitution"). The Federal Constitution delineates the mandates, responsibilities and jurisdictions of the Federal and State Governments ${ }^{6}$. This is the essence of federalism that has been described as "the establishment of a single political system, within which, general and regional governments are assigned to coordinate authority (rights and powers) such that neither level of government is legally or politically subordinate to the other"

Land is listed in the State List together with agriculture, forestry and water. Thus, this effectively places the State Authority ${ }^{8}$ as the ultimate authority

\footnotetext{
${ }^{4}$ United Nation, 1962 p. 89

"Chapter 28 of Agenda 21: "Local Authorities' Activities in Support of Agenda 21"

${ }^{6}$ See articles 74, 95B and Schedules 9-10 of the Federal Constitution of Malaysia of 1957; see also Item 2, State List, Ninth Schedule, Constitution of Malaysia.

${ }^{7}$ Watts, R.L, New Federations: Experiments in the Commonwealth, (Oxford, Clarendon Press, 1966) at p.13.

${ }^{8}$ State Authority, refers to the Ruler or Yang di-Pertua Negeri of a State and includes, in Negeri Sembilan, the Yang di-Pertuan Besar acting on behalf of himself and the Ruling Chiefs (see Section 3 of the Interpretation Acts 1948 and 1967). The term includes the decision making body in the highest hierarchy in a State. Refer Sentul Murni Sdn. Bhd. v Ahmad Amiruddin Bin Kamaruddin \& Ors. [2000] 4 MLJ 503.
} 
for matters related to all land dealings, including alienation, subdivision, type of land use, extraction or minerals, compulsory acquisition and reservation of land. Local government is a matter listed in the State List, thus empowering the State Authorities to organise local governments and municipal services. ${ }^{9}$ Local governments established under the Local Government Act 1976 ("Act 171") are primarily responsible for health, sanitary condition, amenities and the general well being of its residents, and administration of matters relating to land planning and development control by the powers conferred by Act 172. The administration of the planning system and development control is within the exclusive powers of the state and local governments despite of their relying heavily on the Federal government for funds and other resources. ${ }^{10}$

The State Authorities are responsible for organising the local government and municipal services and assume the position of "central government" to the local authority. The local authority in Malaysia is the principal government agency empowered to exercise control at the local level. This gives rise to lack of uniformity in the administration of town and country planning laws in the states of Malaysia, despite Act 172 manifesting its aim of promoting uniformity in the planning law in the West Peninsular Malaysian states. "Sensing the lack of uniformity in the implementation of the planning legislation and rules in the States, the National Physical Planning Council was established in 2002, to ensure some form of coordination in implementing and enforcing of planning laws in all the states as envisaged by the Federal government principally to promote sustainable development and also overcome regional economic imbalances. ${ }^{12}$ However, the Council's power to control the States' or the local planning authority in regulating land use planning has yet to be tested in a court of law.

\section{LEGAL REGULATORY FRAMEWORK}

The Act 171 provides various powers for local authority for regulating local authority areas for ensuring proper administration of affairs of local authority areas to ensure comfort of the residents in the area. The local authorities in

\footnotetext{
${ }^{9}$ Local Government Act 1976 s 3

10 For a detailed discussion on the historical aspects related to organisation of the Malaysian Local Government System, can refer Taylor W.C., Local Government in Malaya, (Alor Setar, Kedah Government Press, 1949).

${ }^{11}$ Town and Country Planning Act 1976 Preamble

12 The provision on the National Physical Planning Council was inserted into the Town and Country Planning Act 1976 by the Town and Country Planning (Amendment) Act 2001 (Act A1129) s 7 wef on $1^{\text {s1 }}$ March 2002.
} 
Malaysia have been vested with discretionary powers by Act 171 . The functions not only include mandatory functions but discretionary functions as well. The mandatory functions include all critical functions such as refuse collection, street lighting and activities pertaining to public health. Discretionary functions include all development functions such as providing amenities, recreational parks, housing and commercial activities. The provisions of the Local Government Act grant the local authorities the roles of local planning authority; licensing authority; taxation authority with power to impose certain kinds of taxes; Undertake building, housing and commercial construction (markets, hawker stalls etc.); Power to perform urban planning and management functions; Traffic management and control (manage urban public transport systems); and Power to plan and provide public utilities.

Act 171 provides local authorities in Malaysia with a very comprehensive set of functions and responsibilities. Two other major legislations are Act 172, and the Street, Drainage and Building Act (1974), help local governments to perform their functions under the Act 171. The legislation allows the local authorities to assume developmental functions in the field of urban management and play a more dynamic role in national development. According to Mohamed Afandi, the provision of the related local government laws empowers the local authorities to carry out a whole range of functions, limited only by their own ambitions and resources. ${ }^{13}$ The major functions of local authorities can be summarized as environmental, public, social and developmental. The functioning of local authority is based on the principle of ultra-vires and general competence as such it may perform those functions as specifically enumerated in the legislation, bylaws and rules. It has no general competence to undertake any activity according to affordability, it cannot undertake any activity that is beyond its powers or else it can be declared as ultra-vires. It is a body corporate that can sue and be sued.

Act 172 confers on the local authority the powers to control land use planning, control and conservation of all lands and buildings within their local authority area. ${ }^{14}$ In areas within a State, which does not come under the jurisdiction of any local authority area, the State Director will assume the role of the local planning authority. Act 172 is applicable to all the local planning authorities in the states of Peninsular Malaysia with the exception of the Federal Territory. The Federal Territory planning authority is governed by the Federal

13 Mohamed Afandi, Local Government Restructuring in Peninsular Malaysia: A Review of the Local Authority Function and Capacity, in Planning and Administration, Volume 16 No. 2, Autumn, IULA, The Hague, 1989 at p. 125.

${ }^{14}$ Town and Country Planning Act 1976 s 5. 
Territory (Planning) Act 1982 (Act 267). The East Malaysian states of Sabah and Sarawak are regulated by other legislation and are not bound by Act $172 .{ }^{15}$

The local authority assumes the functions of a local planning authority as conferred by section 5 of Act 172 and carries out the following functions: ${ }^{16}$

(a) To regulate, control, and plan the development and use of all lands and buildings within its area;

(b) To undertake, assist in, and encourage the collection, maintenance, and publication of statistics, bulletins, and monographs, and other publications relating to town and country planning and its methodology; and

(c) To perform such other functions as the State Authority or the Committee may from time to time assign to it.

The local planning authority can perform all other functions that are supplemental, incidental, or consequential to any of its specified functions and do all such things as may be necessary or expedient for carrying out its planning functions under Act $172 .{ }^{17}$

\section{LAND PLANNING AND DEVELOPMENT CONTROL FUNCTIONS}

The local planning authority is required to prepare a local plan for the whole of its area for purposes of guiding it in planning development in its area. ${ }^{18} \mathrm{~A}$ local plan is a written statement prepared to elaborate the policies and proposals set out in the structure plan. It comprises of written statement and diagrams setting out the detailed planning, and manner of executing and implementing the proposals set out in the structure plan of a local planning authority area. The principal aim of the local plan is to prepare a land use plan in accordance with the procedural requirements set out in of Act 172 and the Development Plans Rules taking into consideration all the national and state land use and development policies. The local plan will be a reference for the local planning authority, government departments and agencies as well as the private sector in the process of planning of land development activities. The functions of the local plan is to interpret the policies and representations from the public

${ }^{15}$ Law applicable to the State of Sabah is the Town and Country Planning Ordinance 1950 of Sabah [Sabah Cap.141] and law applicable to Sarawak is the Town and Country Planning Ordinance 1952 of Sarawak [Sarawak Cap.87];

${ }^{16}$ Functions as prescribed in Town and Country Planning Act $1976 \mathrm{~s} 6(1)$

${ }^{17}$ Town and Country Planning Act 1976 s 6(2)

${ }^{18}$ Town and Country Planning Act 1976 s 12(2) 
incorporated in the structure plan and to implement such aspects in line with the social development, economic and use of resources in a local planning authority area. The local plan is also important in setting out the basic guidelines for the local planning authority, and to identify the aspects related to the action areas which are in need of urgent attention. A local plan in respect of a local planning authority area may be prepared by the local planning authority before the approval of a draft structure plan if they consider it worth having.

In formulating its proposals in a draft local plan, the local planning authority is required to confirm that the proposals conform generally to the structure plan for the State, irrespective as to whether the plan has come into effect, and is required to have regard of any information and other considerations that appears to it to be relevant, or prescribed, ${ }^{19}$ or that the Committee can in any particular case direct it to take into account. ${ }^{20}$ The local planning authority, upon being directed by the Committee as soon as practicable is required to prepare for that part a draft local plan of such nature as may be specified in the direction. ${ }^{21}$

Act 172 does not expressly provide that planning permission must be granted if the development in respect of which permission is applied for would not contravene any provision of the development plan. Planning permission could be refused even if the development in respect of which permission is applied for would not contravene any provision of the development plan. In Chong \& Co. Sdn Bhd v Majlis Perbandaran Pulau Pinang ${ }^{22}$ it was decided that even if the development in respect of which permission was applied would not contravene any provision of the structure plan, planning permission could be validly refused on account of the provisions that the planning authority thinks are likely to be made in any development under preparation or to be prepared, or the proposals relating to those proposals. The development plan was definitely not the only matter to be taken into consideration.

It is the responsibility of the planning authority to plan and enforce laws to ensure managed and orderly growth of their local authority areas. Local authority is also entrusted to realise the government's development policies and assist in revitalising the economy of their local authority area. The planning authority exercises control over land development activities by making it

\footnotetext{
${ }^{19}$ Prescribed by the Committee pursuant to the powers vested on it by the Town and Country Planning Act 1976

${ }^{20}$ Town and Country Planning Act 1976 s $12(8)$

21 Town and Country Planning Act 1976 s 12 (6)

${ }^{22}$ Chong \& Co Sdn Bhd v Majlis Perbandaran Pulau Pinang [2000] 5 MLJ 130
} 
compulsory to obtain planning permission prior to carrying out any land development activity. ${ }^{23}$

The planning authorities have powers to issue directions for developments involving the erection of a building. ${ }^{24}$ However, issuance of such directions cannot be deemed as approval of an application. The local planning authority reserves the right to reject any application even if an application has complied with the required directions. In Tetuan Sri Bangunan Sdn Bhd v Majlis Perbandaran Pulau Pinang, ${ }^{25}$ the court held that directions made by the local planning authority under section 21(3) of Act 172 are not a decision made under section 22(3) of Act 172 .

This powers could possibly be used to impose absurd, unjust and inequitable directions, which may leave the applicant aggrieved and without any course of appeal. Act 172 is silent as to the recourse that is available to an applicant who does not agree with the directions imposed pursuant to section 21 of Act 172. The applicant must amend the building plan to ensure they take abroad all the directions made by the local planning authority. If the applicant fails to amend and resubmit the application within the specified time, then he is deemed to have withdrawn the application. ${ }^{26}$ Appeal against the issuance of directions cannot be made to the Appeal Board established pursuant to section 36 of Act 172. Appeal can only be made against a decision made under section 22(3) of Act 172 where the local planning authority makes a decision on the application for planning permission either approve, approve subject to conditions or reject altogether the application.

The planning authority is required to consult other related government agencies and statutory bodies to obtain their views and recommendations on a proposed development. ${ }^{27}$ This is important to ensure such all development will comply with stipulations prescribed by other statutes and relevant government regulatory agencies. ${ }^{28}$

\footnotetext{
23 Town and Country Planning Act 1976 S 19(1)

${ }^{24}$ Town and Country Planning Act 1976 s 21 (3)

${ }^{25}$ Tetuan Sri Bangunan Sdn. Bhd. v Majlis Perbandaran Pulau Pinang [2006]

${ }^{26}$ Town and Country Planning Act 1976 s 22(5); See Tetuan Sri Bangunan Sdn. Bhd. v Majlis Perbandaran Pulau Pinang [1998] 2 AMR 1053.

${ }^{27}$ Town and Country Planning Act 1976 s 22(1)

${ }^{28}$ Rule 9 Town and Country Planning Act 1976 Planning Control (General) Rules 1990
} 
In Bencon Development Sdn. Bhd. v Majlis Perbandaran Pulau Pinang, ${ }^{29}$ the court held that the Majlis Perbandaran Pulau Pinang as the approving authority should obtain technical advises from other relevant government departments. Act 172 has not provided the mode of consultation and the authorities to be consulted. This also gives the local planning authority the discretion on deciding the mode of consultation and consideration of the input.

The local planning authority is also required to notify applications for planning permission to provide an opportunity for the adjoining neighbour of the proposed development to make objections. ${ }^{30}$ This is an important process wherein it provides, the adjoining neighbour (landowner) with the opportunity to put forward their views on the proposed development that may pose adverse impact to their property or person. However, such right to participate is only available if there is no local plan for the area involved. ${ }^{3 !}$ It is suggested that it would be useful for ensuring proper planning practice if adjoining neighbour can be permitted to participate in the decision making process irrespective if there is a local plan in existence or not.

\section{PROTECTION AND INDEMNITY IN PERFORMANCE OF FUNCTIONS}

Local authority and its agents are deemed to be public servants. Every member and agent of the local planning authority, every authorized person, and every assistant or workman accompanying or assisting an authorized person in the performance of his functions under Act 172 will be deemed to be public servants for the purposes of the Penal Code. ${ }^{32}$ The Public Authorities Protection Act 1948 (Act 198) is applicable to any action, suit, prosecution, or proceeding against the local planning authority, every member and agent, every member of the Appeal Board, every authorized person, and every assistant or workman accompanying or assisting an authorized person in the performance of his functions under Act 172, in respect of any act, neglect, or default done or committed by the authority, member, person, assistant, or workman in his

${ }^{29}$ Bencon Development Sdn. Bhd. v Majlis Perbandaran Pulau Pinang [1999] 2 MLJ 385; See also Chong \& Co v Majlis Perbandaran Pulau Pinang [2000] 5 MLJ 130

30 Town and Country Planning Act 1976 s 21(6): Refer also case of Ah San@GohAh Soon v Majlis Bandaraya Ipoh \& Ors [2000] 1 MLJ 615

${ }^{3 !}$ In Leila Dulcie Allana Labrooy \& 9 Ors. v Majlis Bandaraya Ipoh \& Anor [1995] 4 CLJ 727.

${ }^{32}$ Town and Country Planning Act 1976 s 53 
capacity as such. ${ }^{33}$ Section 54 of Act 172 , provides protection for the officers who, in administering the planning functions as provided in Act 172, carry out their duties in good faith in accordance with their statutory powers. The court interpreted the term local authority to exclude the government of Malaysia, where it said that local authorities and Government of Malaysia are distinct bodies. $^{34}$

No matter or thing done and no contract entered into by any State Authority and no matter or thing done by any officer employed in the administration of the the planning functions, ${ }^{2}$ or other persons acting under the direction of the State Authority will if the matter or thing was done or the contract was entered into in good faith (bona fide) for the purpose of executing the functions entrusted by law, subject them or any of them personally to any action, liability, claim or demand whatsoever ${ }^{3}$.

The State Authority, local authority ${ }^{4}$ and any public officer or officer or employee of the local authority may not be subject to any action, claim, liabilities or demand whatsoever arising out of any building ${ }^{5}$ or other works carried out in accordance with the provisions of the Act or any by- laws ${ }^{6}$ made under it or by reason of the fact that such building works or the plans thereof are subject to inspection and approval by the State Authority, local authority or such public officer or officer or employee of the State Authority or the local authority and nothing in the Act or any by- laws made under it may make it obligatory for the State Authority or the local authority to inspect any building, building to ascertain that the provisions of the Act or by-laws are complied with or that plans, certificates and notices ${ }^{7}$ submitted to him are accurate ${ }^{8}$. Any expenses incurred the State Authority, officer or other person acting in accordance with the above provisions will be borne by the local authority?

The court in Steven Phoa Cheng Loon \& Ors v Highland Properties Sdn $B h d \&$ Ors. ${ }^{35}$ when asked to decided on the liability of the officer of the local authority held that by the provisions of sections $5,6(1), 6(4)$, and 18 of the Government Proceedings Act, the particular officer or officers in the Government who committed the tortuous wrong must be identified otherwise the claim against government will fail. Section 5 of the Government

${ }^{33}$ Town and Country Planning Act 1976 s 54; Refer Baltim Timber Sdn Bhd v Director of Forests \& Ors [1996] 4 MLJ 103 for related discussion on the protection of public authorities in performing their official functions.

${ }^{34}$ see Lee Hun Hoe CJ in Government of Malaysia \& Anor v Akasah Bin Ahad [1986] 1 MLJ 396 at p.399.

${ }^{35}$ Steven Phoa Cheng Loon \& Ors v Highland Properties Sdn Bhd \& Ors [2000] 4 MLJ 200 
Proceedings Act $1956^{36}$ provides that, subject to the Act, the Government shall be liable for any wrongful act done or any neglect or default committed by any public officer in the same manner and to the same extent as that in which a principal, being a private person, is liable for any wrongful act done, or any neglect or default committed by his agent, and for the purposes of this section and without prejudice to the generality thereof, any public officer acting or purporting in good faith to be acting in pursuance of a duty imposed by law shall be deemed to be the agent of and to be acting under the instructions of section 6(1) of the Government Proceedings Act 1956 that provides that no proceeding can be brought against the Government by virtue of section 5 in respect of any act, neglect or default of any public officer, unless proceedings for damages in respect of such act, neglect or default would have lain against such officer personally. The Court decided that the local authority is protected by virtue of the provision of section 95(2) of the Street, Drainage and Building Act 1974.

The local authorities are also protected by sections 123-126 of the Local Government Act 1976. In Dr Abdul Hamid Abdul Rashid \& Anor v Jurusan Malaysia Consultants, ${ }^{37}$ the Court supporting the concept of economical loss is recoverable said that, "If there is any fear that this approach may encumber the local authorities to pay out substantial claims due to their negligence in granting approvals or inspecting building works, there is section 95 of the Street, Drainage and Building Act 1974 which prohibits such authorities to be sued.

\section{JUDICIAL AUTHORITY OVER LOCAL PLANNING AUTHORITY}

The statute confers wide discretionary powers to the planning authorities. Judicial control and central government policy is available in Malaysia to ensure some form of control over the decisions. However, judicial control of the discretionary powers to impose planning conditions in Malaysia is relatively undeveloped. Thus, reference is often made to the English courts, which have developed legal tests for the validity of planning conditions over the years. Malaysian courts have accepted the reasonableness test pronounced by Lord Greene MR in Associated Provincial Picture Houses Limited v Wednesbury

\footnotetext{
${ }^{36}$ Government Proceedings Act $1956 \mathrm{~s} 5$

${ }^{37}$ Dr Abdul Hamid Abdul Rashid \& Anor v Jurusan Malaysia Consultants [1997] 3 MLJ 546
} 


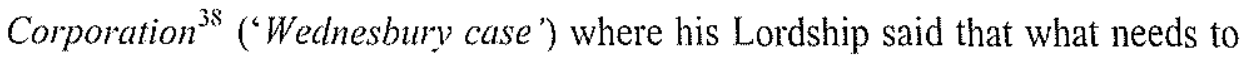
be determined is as to whether the local planning authority in imposing a condition had acted reasonably.

The local planning authority has power "to impose such conditions" as it thinks fit to impose" on a grant of planning permission. The conditions are stipulated in section 21(3) of Act 172. In Dr Benjamin George \& Ors v Majlis Perbandaran Ampang Jaya \& Ors,${ }^{40}$ it was held that the conditions that can be imposed on an application for planning permission by the local planning authority are pursuant to provisions of section 21(3) of Act 172. The conditions that may be imposed by the local planning authority can also be based on the matters related to the development proposal report and the layout plans. ${ }^{4 !}$ In Chong \& Co. Sdn. Bhd. $v$ Majlis Perbandaran Pulau Pinang, ${ }^{42}$ the court affirmed the rights of the local planning authority to impose such conditions as it "thinks fit."

The directions imposed by the local planning authority pursuant to the provisions of section 21(3) of Act 172 cannot be made subject to an appeal to any other authorities since right to appeal is only in respect of the decision made pursuant to section 22(3) of Act 172. The provisions of s 23(2) of Act 172 cannot be circumvented by directions under s 21 or by indecision. A local planning authority must decide on an application for planning permission. It is the intention of Act 172 that there is a speedy disposal of applications for planning permission and a right of appeal to aggrieved applicants. The application of the words in Act 172 must produce that result and that result would be produced only by construing the word 'decision' not only in the literal sense (grant or refusal of planning permission) but also in the wider sense (no decision on the application), so that a local planning authority could not refuse to decide on an application, and also so that an applicant who would be aggrieved by no decision could appeal to the Appeal Board. The Planning Appeal Board is also not empowered to entertain appeals against the decision of the local planning authority to give directions pursuant to the provisions of section 21(3) of Act 172.

\footnotetext{
38 Associated Provincial Picture Houses Limited v Wednesbury Corporation [1948] 1 KB 223.

39 "Subject to such conditions", see Town and Country Planning Act $1976 \mathrm{~s} 22(5)$ as to the conditional grant of planning permission.

${ }^{40}$ Dr Benjamin George \& Ors. v Majlis Perbandaran Ampang Jaya \& Ors. [1995] 3 MLJ 665.

${ }^{41}$ Town and Country Planning Act 1976 s $21 \mathrm{~B}$ on preparation of layout plans and s $21 \mathrm{~A}$ on development proposal report and matters to be included in such plans.

${ }^{42}$ Chong \& Co. Sdn. Bhd. v Majlis Perbandaran Pulau Pinang [2000] 5 MLJ 130.
} 
The statutory guidance appears to be rather limited, thus conferring wide powers to the planning authorities. Judicial control and central government policy is available in Malaysia to ensure some form of control over the decisions. However, judicial control of the discretionary powers to impose planning conditions in Malaysia is relatively undeveloped. Thus, reference is often made to the English courts, which have developed legal tests for the validity of planning conditions over the years. Malaysian courts have accepted the reasonableness test pronounced by Lord Greene MR in the Wednesbury case $^{43}$ where his Lordship said that what needs to be determined is as to whether the local planning authority in imposing a condition had acted reasonably.

Suffian L.P. in Pengarah Tanah dan Galian Wilayah Persekutuan v Sri Lempah Enterprise Sdn. Bhd. ${ }^{44}$ ("Sri Lempah case") was approached to decide as to whether the condition imposed on the landowner by the planning authority is valid. The court expounded the following principles could be followed in determining the validity of planning conditions: ${ }^{45}$

a. the approving authority does not have an uncontrolled discretion to impose whatever conditions it likes;

b. the conditions to be valid, must fairly and reasonably relate to the permitted development;

c. the approving authority must act reasonably and planning conditions must be reasonable;

d. the approving authority is not at liberty to use its power for an ulterior object, however desirable that object may seem to be in the public interest.

Therefore, in exercising its discretion in approving an application for planning permission, the planning authorities is required to have regard to all relevant considerations, disregard all improper considerations and produce a result, which does not offend against common sense as decided by Lord Greene in Associated Provincial Picture Houses Ltd $v$ Wednesbury Corporation. ${ }^{46}$

${ }^{43}$ Associated Provincial Picture Houses Limited v Wednesbury Corporation [1948] 1 KB 223.

${ }^{44}$ Pengarah Tanah dan Galian Wilayah Persekutuan v Sri Lempah Enterprise Sdn. Bhd.[1979] I MLJ 135.

${ }^{45}$ Followed Fawcett Properties v Buckingham County Council (1950) Ch 543 (CA) and (1961) AC 636 (HL).

${ }^{46}$ Associated Provincial Picture Houses Ltd v Wednesbuy Corporation[1948]1 KB 223 
In Majlis Perbandaran Pulau Pinang $v$ Syarikat Bekerjasama-sama Serbaguna Sungai Gelugor dengan Tanggungan, ${ }^{47}$ ("Syarikat Bekerjasama") the Federal Court had to decide whether it was permissible for a planning authority to impose a planning condition relating to affordable housing accommodation and used the following tests:

a. they must be imposed for a planning purpose and not for an ulterior motive;

b. they must fairly and reasonably relate to the development permitted; and

c. they must not be perverse ("so unreasonable that no reasonable authority could have imposed them").

On the first point, the court determined whether affordable housing was a permissible planning purpose. After considering the Structure Plan policies containing stipulations as to affordable housing and section 8(4) of Act 172 as to the relevancy of current policies in formulating the Structure Plan, the court held that the appellant has the power to impose a planning condition to give effect to affordable housing. ${ }^{48}$ The court decided on the second point that the imposition of the condition was not ultra vires the powers of the planning authority.

In Rethina Development Sdn. Bhd. $v$ Majlis Perbandaran Seberang Perai, Butterworth, ${ }^{49}$ Rethina Development (plaintiff) applied for and obtained planning permission to build flats and shophouses in a housing scheme. In the layout plan approved by the Council, it required the developer to carry out landscaping and tree planting. The developer agreed to the requirement and to pay monetary contribution to the Council at the fixed rate. The issue before the court was whether the Council was empowered to impose monetary contributions in lieu of complying with an agreed planning condition. The court in deciding in favour of the developer granted the orders. The court held that any direction to a developer for carrying out landscaping and planting of trees in a housing scheme does not come within the meaning of 'any other matter' in section 21(3) of Act 172 which the local planning authority considers necessary for the purposes of planning. The local planning authority is not empowered in law to demand for payment of monetary contribution for landscaping and tree

${ }^{47}$ Majlis Perbandaran Pulau Pinang v Syarikat Bekerjasama-sama Serbaguna Sungai Gelugor dengan Tanggungan [1999] 3 MLJ 1

48 Ibid at p.54.

${ }^{49}$ Rethina Development Sdn. Bhd. v Majlis Perbandaran Seberang Perai, Butterworth [1990] 2 MLJ 111 
planting in lieu of the requirement imposed on the developer. In the circumstances the Council was ordered to refund all the monies collected from the developer.

The authorities are not at liberty to use their powers for an ulterior object; however, desirable that object may seem to them to be in the public interest. If they mistake or misuse their powers, even in good faith, the Court can interfere by declaration and injunction. Thus, the powers of the local planning authorities to impose planning conditions are not uncontrolled. The Malaysian courts, however, often refrain from reviewing the decision of the planning authorities because such decisions involve policy consideration and the courts do not possess knowledge of the policy considerations which underlie such decisions ${ }^{150}{ }^{50}$ In Sri Lempah case, ${ }^{51}$ it was held that the court is not an appellate authority that has more powers than the approving authority but merely a judicial authority is authorized to examine as to whether the approving authority has acted outside the statutory powers. Further, no court should pretend that it knows more or better about town planning than town planners themselves. Courts are concerned with law, not planning.

\section{CONCLUSION}

The law enacted to regulate affairs of local authority vests wide discretionary powers on the local authorities in the course of exercising its functions related to administration, planning and development control in local authority areas. These powers are necessary to help them execute the vast responsibilities entrusted upon them. The power to indemnify local authorities against losses arising from negligence is a necessary evil. However, this power must not be left unchecked since it can lead to abuse of discretion. The courts very often refrain from controlling the powers of the local planning authorities. Analysis of case law amplifies the fact that the discretionary powers are not absolutely free from judicial check and control. Similar to any other administrative or government agent, the local authority must use their powers judiciously and within the limits of the powers prescribed by law to prevent the court from questioning their decisions.

\footnotetext{
${ }^{50}$ Datuk Bandar Kuala Lumpur v Zain Azahari bin Zainal Abidin [1997] 2 MLJ 17.

${ }^{51}$ Pengarah Tanah dan Galian Wilayah Persekutuan v Sri Lempah Enterprise Sdn.Bhd. [1979] 1 MLJ 135 (FC).
} 


\section{REFERENCES}

\section{Books/Journals:}

Taylor W.C., 1949. Local Government in Malaya, Alor Setar: Kedah Government Press.

Watts, R.L., 1966. New Federations: Experiments in the Commonwealth, Oxford: Clarendon Press.

Mohamed Afandi, 1989. Local Government Restructuring in Peninsular Malaysia: A Review of the Local Authority Function and Capacity, in Planning and Administration, Volume 16 No. 2, Autumn, IULA: The Hague, p. 125.

\section{Statutes:}

Federal Constitution of Malaysia 1957

Interpretation Acts 1948 and 1967 (Act 388)

Government Proceedings Act 1956 s 5

Local Government Act 1976 (Act 171)

Planning Control (General) Rules 1990

Street Drainage and Building Act 1974 (Act 133)

Town and Country Planning Act 1976 (Act 172)

Federal Territory (Planning) Act 1982 (Act 267)

Town and Country Planning Ordinance 1950 of Sabah (Sabah Cap.141)

Town and Country Planning Ordinance 1952 of Sarawak (Sarawak Cap.87) 
